\title{
ENERGY AND EMISSION ANALYSES OF A SOLAR ENERGY BASED DISTRICT HEATING SYSTEM
}

\author{
Cristina CALIN ${ }^{a *}$, Eugen Victor RUSU ${ }^{b}$, Ion ION ${ }^{b}$, Gabriel MOCANU $^{b}$ \\ a "Calorgal S.A., 6 Crizantemelor, Galati, ROMANIA \\ b "University of “Dunarea de Jos", Faculty of Engineering, 47 Domnească, RO-800008, Galati, ROMANIA \\ * Corresponding author: cristina.calin@ugal.ro
}

\begin{abstract}
The energy, economic and environmental analysis of a solar heating system with seasonal heat storage integrated into a district heating system based on natural gas boiler was performed. The solar collector field has a surface area of $8720 \mathrm{~m}^{2}$ and the pit seasonal heat storage has a volume of $10000 \mathrm{~m}^{3}$. This system covers $79 \%$ of the total yearly heat demand of the 15 multifamily buildings with 1500 inhabitants. The total system investment cost (2974100 €) may be recovered in about 17 years. The environmental impact of solar heating system integration is the decrease of $\mathrm{CO}_{2}$ emission by $79 \%$.
\end{abstract}

Keywords: environmental, seasonal heat, natural gas, buildings, integration.

\section{INTRODUCTION}

The whole heating and cooling in buildings and industry sector in EU accounts for 50\% of the EU's annual energy consumption. It shares $13 \%$ of oil consumption and $59 \%$ of total gas consumption (direct use only). The renewable energy sources accounts for only $18 \%$ (11\% biomass; $7 \%$ wind, PV and hydro; $1.5 \%$ solar thermal energy, ambient heat and geothermal energy) of primary energy consumption in the heating and cooling sector. The amount of wasted heat from industrial processes in the EU can cover the EU's entire heating needs in residential and tertiary buildings [1].

The basic fundamental idea of district heating is associated with combined heat and power generation systems (CHP). Integration of renewable energy sources into district heating systems has a substantial potential in reducing primary energy consumptions, carbon dioxide emissions and costs in the European Union. The use of power-to-heat installations in district heating systems offers flexibility in the electricity system, when alternative options for heat supply and thermal energy storage systems are available in district heating systems. They also are competitive due to the low specific investment and installation costs for large electric boilers, heat pumps and heat storages [2].

The use of renewable energy sources in DHS requires high initial investment, but, it is beneficial in term of socio-economic and environmental sustainability [3, 4].

Solar heating and cooling technologies are spreading in several countries, especially in locations with high annual solar radiation. There are many examples for integration of solar thermal systems into district heating networks, especially in Denmark, Sweden, Austria, Germany, Spain and Greece [512].

The use of thermal energy storage and seasonal storage (to accumulate the summer overproduction of solar systems) covering a variable thermal demand has a proved economic interest in solar systems and polygeneration systems for district heating and cooling in the residential and commercial sector [12].

For solar district heating (SDH) systems, the share of solar energy is a base indicator for system design and long term operation. The method for determining optimal utilization rate for solar energy under different climates and economic conditions is based on economic evaluation, by considering annual cost, annual operating expenses and investment payback time [6].

The SDH systems are particularly suitable for small towns, where the heating price is higher due to higher relative network heat losses and higher heat production price by using mainly natural gas. The smaller towns have the advantage that land areas suitable for solar collector fields are usually closer to the DH [13]. 
The heat price of natural gas boilers in EU can be the highest one, higher than $60 € / \mathrm{MWh}$. The price of heat generated in solar heating plant is in the range of 20-40 €/MWh, much lower than the price of heat generated in natural gas boilers which is $67 € / \mathrm{MWh}$ in EU [14].

In Romania, the solar energy is used for electrical power generation (on-grid and off-grid) and hot water production for sanitary uses. The largest solar thermal system for domestic hot water production is in City of Giurgiu and consists of $300 \mathrm{~m}^{2}$ of solar collectors installed on two apartment blocks and 4 heat storage tanks of $5 \mathrm{~m}^{3}$ each. The system supplies with hot water all 80 apartments in blocks from April to November when the district heating system is turned off.

In this paper is analyzed the integration feasibility of a solar thermal system in combination with heat storage and heat pump in a heating system which feeds an isolated district of Galati City, Romania (Fig. 1).
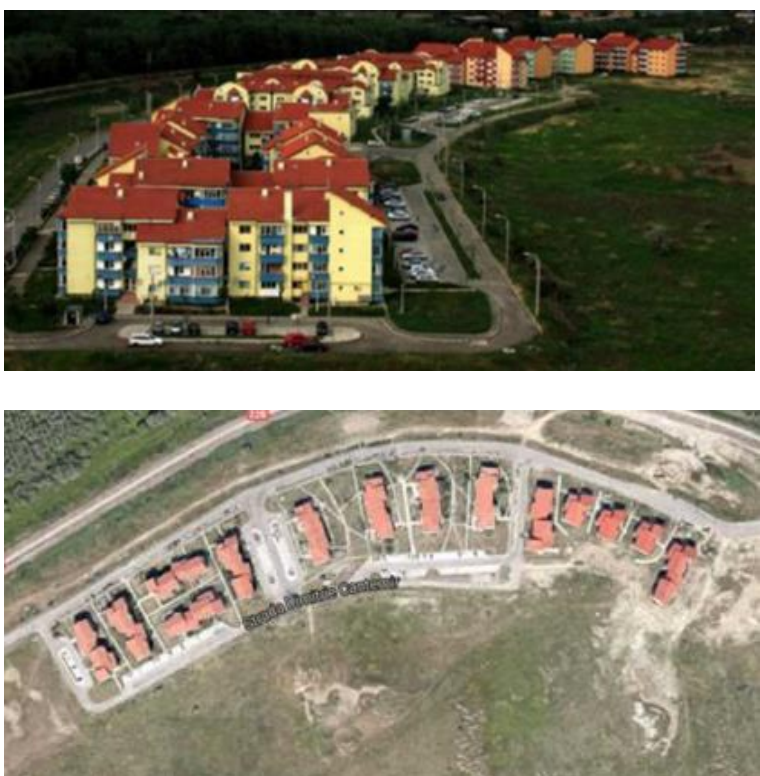

Fig. 1. Photos of the analysed community

The district has 15 multifamily buildings with 1500 inhabitants. The neighborhood is surrounded by free land, devoid of buildings, which allows for installing a solar heating system provided with heat storage. The good solar potential in the area (Fig. 2) and the existence of free space led to the idea of integrating solar energy into the district heating system

Besides the system designs (size of solar thermal system and long term seasonal storage; energy performance) the $\mathrm{CO}_{2}$ emission is analyzed.

\section{DESCRIPTION OF THE DISTRICT HEATING SYSTEM}

The buildings contain one- two- and three-room apartment and communal areas. The heat consumption for domestic hot water and heating was calculated based on monitored gas consumption data during the last two years. The average yearly consumption of natural gas was $607000 \mathrm{Nm}^{3}$ that means $5387 \mathrm{MWh}$.

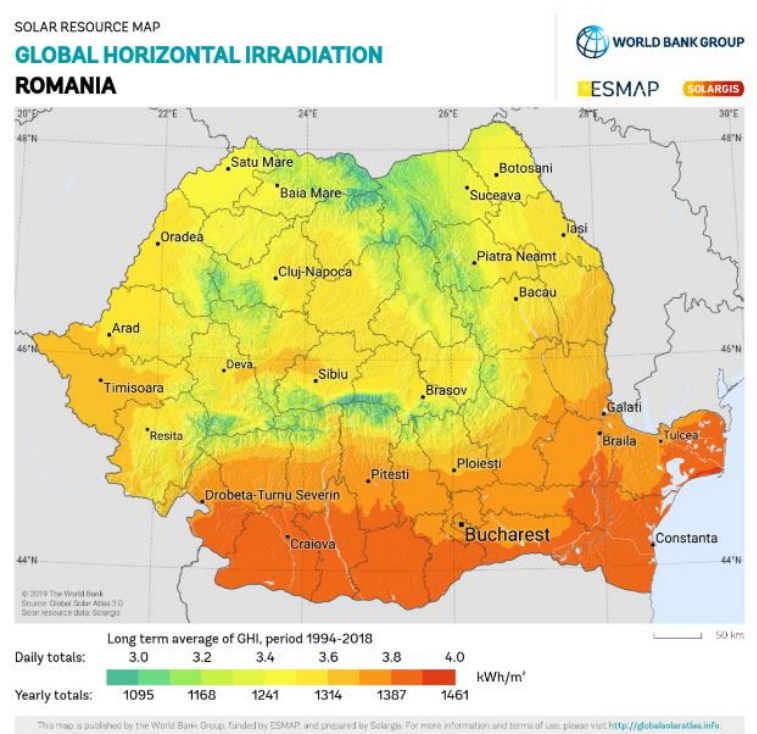

Fig. 2. Global horizontal irradiation in Galati [15]

Figure 3 presents the average monthly heat consumption and atmospheric temperature. On average, an apartment consumes in a year 15480 $\mathrm{kWh}$ of heat.

The proposed system integrates into the existing district heating network, consisting in a natural gas boilers (GB) with total heating capacity of $1.3 \mathrm{MW}$ and 9 buffer storage tanks (BT), a flat plate solar collector circuit (SC) equipped with plate heat exchangers (HE), a pit Seasonal Thermal Energy Storage (PSTES) and water circulating pumps (Fig. $4)$. The heat generated by collectors is transferred in HE to the main working fluid (water), which can feed the STES (during charging period) or is transferred in the DHN, when space heating or domestic hot water is required.

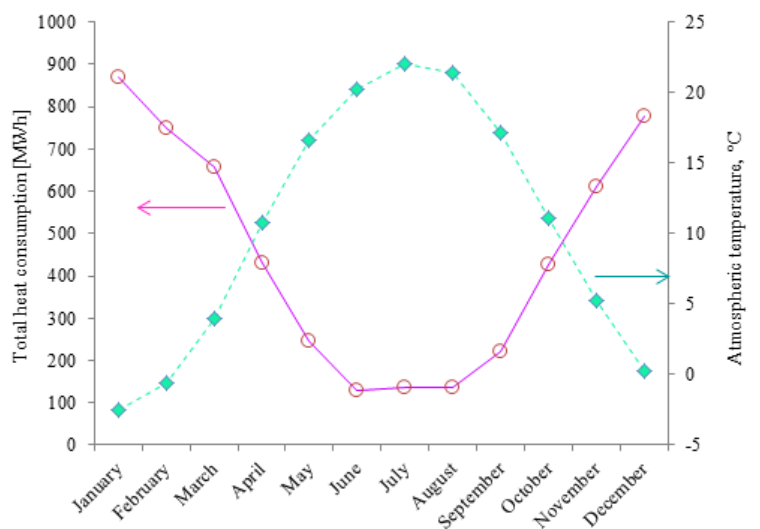

Fig. 3. Monthly total heat consumption and atmospheric temperature 
When the stored heat or the heat coming directly form solar collectors is insufficient to meet the

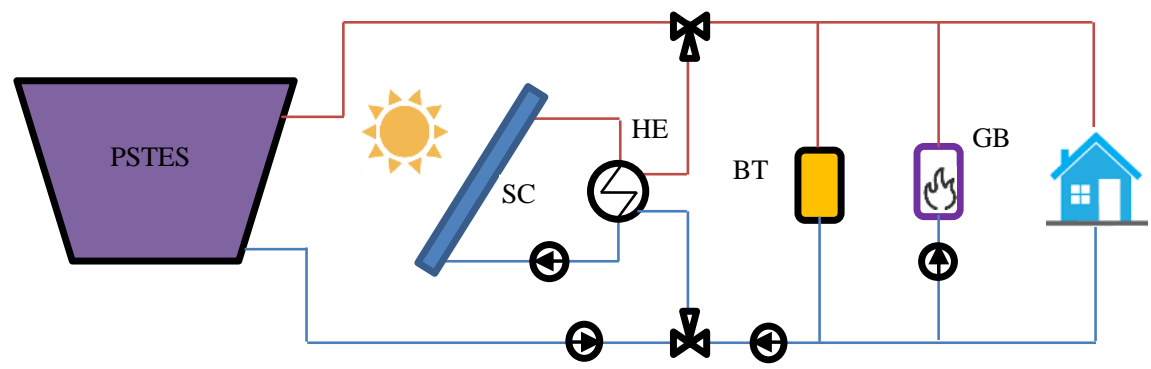

Fig. 4. Schematic of proposed solar heating system.

current heat demand, the natural gas fired boilers (GB) raise the temperature of the district loop as required. The chosen solar collector model is Lifestyle Solar Thermal made by Bosch Thermotechnology (Table 1) [16]. The working fluid of the solar collectors is a mixture of glycol (35\%) and water. The solar collectors are oriented towards south having $46^{\circ}$ tilt, the optimum tilt for maximum output during spring and autumn for the given location. The climatic parameters (monthly ambient temperature, daily total solar radiation energy on horizontal and tilt surfaces) for the location of case study (Galati city at latitude, $\mathrm{N} 45.5^{\circ}$ and longitude, E $28^{\circ}$ ) have been obtained by using the RetScreen software [17].

Table 1. Characteristics of seasonal thermal energy storage system

\begin{tabular}{lc}
\hline \multicolumn{2}{c}{ Solar collectors [16] } \\
\hline Solar collectors type & flat plate, glazed \\
Optical efficiency, $\eta_{0}$ & 0.77 \\
First-order coefficient, $k_{1}$ & $3.871 \mathrm{~W} /\left(\mathrm{m}^{2} \mathrm{~K}\right)$ \\
Second-order coefficient, $k_{2}$ & $0.012 \mathrm{~W} /\left(\mathrm{m}^{2} \cdot \mathrm{K}^{2}\right)$ \\
Incidence Angle $\quad$ Modifier 0.92 \\
$(\mathrm{IAM})\left(50^{\circ}\right)$ & $2.18 \mathrm{~m}^{2}$ \\
Absorber area $\left(A_{s c}\right)$ & $501 / \mathrm{h}$ \\
Nominal flow rate & \\
\hline \multicolumn{2}{l}{ Pit Seasonal Thermal Energy Storage (PSTES) }
\end{tabular}

Pit Seasonal Thermal Energy Storage (PSTES)
Dimensions: $h \quad 10 \times 42 \times 20 \mathrm{~m}$
x $b$

\begin{tabular}{lc}
\hline Volume: \\
$V=\frac{h}{3}\left(a^{2}+b^{2}+a b\right)$ & $10000 \mathrm{~m}^{3}$ \\
\hline$T_{\text {top }}$ & $80^{\circ} \mathrm{C}$ \\
\hline$T_{s}$ & $50^{\circ} \mathrm{C}$ \\
\hline$T_{b}$ & $30^{\circ} \mathrm{C}$ \\
\hline$T_{g}$ & $10^{\circ} \mathrm{C}$ \\
\hline$T_{\text {air }}$ & monthly data \\
\hline$\lambda_{\text {top }}$ & $0.104 \mathrm{~W} /(\mathrm{m} \cdot \mathrm{K})[18]$ \\
\hline$\lambda_{w}$ & $0.5 \mathrm{~W} /(\mathrm{m} \cdot \mathrm{K})[18]$ \\
\hline$s_{\text {top }}$ & $240 \mathrm{~mm}$ \\
\hline$s_{w}$ & $700 \mathrm{~mm}$ \\
\hline
\end{tabular}

The pit Seasonal Thermal Energy Storage (PSTES) is a rectangular-shaped water tank which is placed in a ground excavation. The tank ceiling and walls are an assembly of several layers: inner stainless steel lining, concrete and expanded glass granulate as heat insulation. The characteristics of STES are given in Table 1.

The pumps used to circulate hot-water and return water between storage, heaters and district heating network are equipped with variable speed drives in order to minimize power consumption while providing a wide range of thermal powers.

The total area of solar collectors was was chosen according to the guidelines for solar assisted district heating system given in [19] between $1.4 \mathrm{~m}^{2}$ and 2.4 $\mathrm{m}^{2}$ of solar collector per MWh annual heat demand and the storage volume was chosen according to the same guidelines between $1.4 \mathrm{~m}^{3}$ and $2.1 \mathrm{~m}^{3}$ of water per $\mathrm{m}^{2}$ of solar collector.

\section{ENERGY MODEL}

The monthly amount of heat produced by the solar collectors is:

$$
Q_{s c}=\eta_{s c} \times A_{s c} \times N_{d a y} \times G_{T}[\mathrm{kWh}](1)
$$

where

$A_{S C}$ - aperture area of solar collectors, $\mathrm{m}^{2}$, $N_{d a y}$ - number of days in the month,

$G_{T}$ - total solar energy incident on the plane of collector, $\mathrm{kWh} / \mathrm{m}^{2} / \mathrm{day}$,

$\eta_{S C}$-efficiency of solar collectors:

$$
\eta_{s c}=\eta_{0} \times I A M+k_{1} \frac{T_{m}-T_{a}}{G}+k_{2} \frac{\left(T_{m}-T_{a}\right)^{2}}{G}
$$

$\eta_{0}$ - optical efficiency of solar collector;

$I A M$ - Incidence Angle Modifier,

$k_{1}$ - first order loss coefficient, $\mathrm{W} /\left(\mathrm{m}^{2} \cdot \mathrm{K}\right)$,

$k_{2}-$ second order loss coefficient, $\mathrm{W} /\left(\mathrm{m}^{2} \cdot \mathrm{K}^{2}\right)$,

$T_{m}$ - average temperature of working fluid of solar collectors, ${ }^{\circ} \mathrm{C}$,

$T_{a}$ - ambient temperature, ${ }^{\circ} \mathrm{C}$,

$G$ - total solar irradiance on surface of collectors, $\mathrm{kW} / \mathrm{m}^{2}$, 
The heat storage capacity is given by the following equation:

$$
Q_{\text {storaged }}=V \times \rho \times c_{p} \times\left(T_{\text {top }}-T_{b}\right)[\mathrm{kW}]
$$

where

$V$ - volume of the storage, $\mathrm{m}^{3}$,

$\rho$ - water density, $\mathrm{kg} / \mathrm{m}^{3}$,

$c_{p}$ - specific heat capacity of the water, $\mathrm{kJ} /(\mathrm{kg} \cdot \mathrm{K})$,

$T_{\text {top, }} T_{b}$ - temperature in the top and bottom, respectively, $\mathrm{K}$.

The heat losses of storage tank are:

- heat loss from the top:

$$
Q_{\text {tloss }}=\frac{\lambda_{t o p}}{s_{t o p}} \times A_{t o p} \times\left(T_{t o p}-T_{\text {air }}\right)[\mathrm{kW}]
$$

- heat loss from the sides:

$$
Q_{\text {sloss }}=\frac{\lambda_{w}}{s_{w}} \times A_{s} \times\left(T_{s}-T_{g}\right)[\mathrm{kW}]
$$

- heat loss from the bottom:

$$
Q_{\text {bloss }}=\frac{\lambda_{w}}{s_{w}} \times A_{b} \times\left(T_{b}-T_{g}\right)[\mathrm{kW}]
$$

where

$\lambda_{\text {top }}, \lambda_{w}-$ thermal conductivity of tank cover and wall, respectively, $\mathrm{W} /(\mathrm{m} \cdot \mathrm{K})$,

$s_{\text {top }}, s_{w}-$ thickness of tank cover and wall, respectively, $\mathrm{m}$,

$A_{\text {top }}, A_{w}$ - areas of tank cover and wall, respectively, $\mathrm{m}^{2}$,

$T_{s}$ - water average temperature, $\mathrm{K}$,

$T_{\text {air }}, T_{g}$ - air and ground temperature, respectively, $\mathrm{K}$,

$T_{s}, \quad T_{b}$ - water average and base temperature, respectively, $\mathrm{K}$.

\section{RESULTS}

The monthly heat share in the district heating system is presented in Fig. 5 for the conditions described previously. The heat supplied is divided into direct use of solar heat, which is supplied from the solar collectors, heat from the gas boiler and heat from the pit seasonal heat storage system, respectively. All these heat supplies are loaded into the buffer tank and, from there, the heat is delivered into the district heating network.

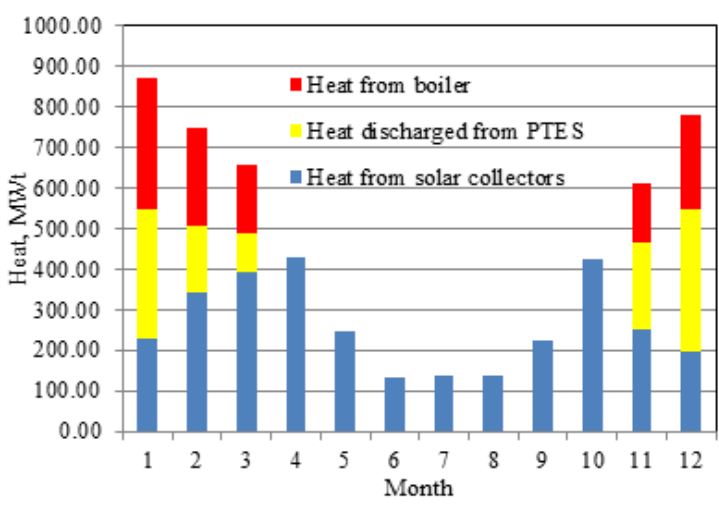

Fig. 5. Monthly heat supply and demand

It may be seen that the solar collectors cover entirely the heat demand during April, May, June, July August, September and October and the excess of heat is stored and then used in November, December, January, February and March. When the amount of stored heat is not enough to cover the demand, the natural gas boiler should deliver the necessary heat. The use of gas boiler is required also by the temperature of stored water, which is lower than the required temperature of the host water in district heating system. The total heat generated by the solar collector field is $4755 \mathrm{MWh}$. The share of heat generated by the solar collectors represents $67 \%$ of total heat supply (Fig. 6). The heat lost from the heat storage system represents around 19\% of the solar yield.

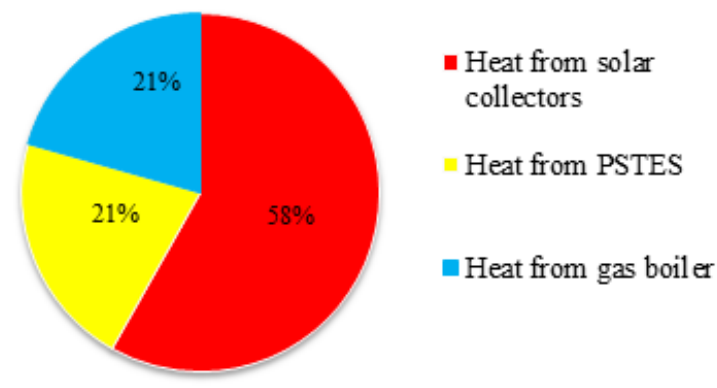

Fig. 6. Monthly heat supply and demand

Considering the following average investment costs: $200 € / \mathrm{m}^{2}$ of aperture area of collectors; $7000 € / \mathrm{m}^{2}$ of land area; $620 € / \mathrm{m}$ of transmission line and $110 € / \mathrm{m}^{3}$ of seasonal heat storage results the total investment cost of $2974100 €$, which can be recovered in about 17 years.

The $\mathrm{CO}_{2}$ emission is reduced by $79 \%$ by integration of solar heating with seasonal heat storing into the district heating system.

The environmental performance can be improved by using a heat pump instead of gas boiler but with a corresponding increase of investment cost

\section{CONCLUSIONS}

This paper investigated the thermal and environmental performance of a solar heating plant with seasonal heat storage integration into a district heating system from Romania. The energy performance results are: a solar energy yield of 4755 MWh/y, a yearly Solar Fraction of $67 \%$, a Summer Solar Fraction of $100 \%$ and an efficiency of seasonal heat storage system of $79 \%$.

The total investment cost of this system is $2974100 €$ and it maybe recovered in about 17 years.

The $\mathrm{CO}_{2}$ emission is decreased much, from 969 $\mathrm{t}_{\mathrm{CO} 2}$ per year to $199 \mathrm{t}_{\mathrm{CO} 2}$ per year.

The use of solar heating system with seasonal heat storage in Galati City represents a very good 
option, given the solar energy potential and the availability of land for solar collector field and seasonal heat storage system.

\section{REFERENCES}

[1] *** European Commission. Towards a smart, efficient and sustainable heating and cooling sector. Brussels, 16 February 2016.

https://ec.europa.eu/commission/presscorner/detail/e n/MEMO_16_311

[2] Halozan H. (2017) The role of heat pumps in renewable heating and cooling, 12th IEA Heat Pump Conference, O.2.1.3

[3] Olsthoorn D., Haghighat F., Mirzaei P.A. (2016) Integration of storage and renewable energy into district heating systems: A review of modelling and optimization, Solar Energy, 136, pp. 49-64.

[4] Ion V.I., Ciocea G., Popescu F. (2012) Energy saving and GHG emission reduction in a MicroCCHP system by use of solar energy, Environmental and Climate Technologies, 10, pp. 16-20.

[5] Kubinski K., Szabłowski Ł. (2020) Dynamic model of solar heating plant with seasonal thermal energy storage, Renewable Energy, 145, pp. 20252033.

[6] Huang J., Fan J., Furbo S., Chen D., Dai Y., Kong W. (2019) Economic analysis and optimization of combined solar district heating technologies and systems, Energy, 186, 115886

[7] Rosato A., Ciervo A., Ciampi G., Sibilio S. (2019) Effects of solar field design on the energy, environmental and economic performance of a solar district heating network serving Italian residential and school buildings, Renewable Energy, 143, pp. 596-610.

[8] Bauer D., Marx R., Nußbicker-Lux J., Ochs F., Heidemann W., Müller-Steinhagen H. (2010) German central solar heating plants with seasonal heat storage, Solar Energy, 84, pp. 612-623.

[9] Olsthoorn D., Haghighat F., Mirzaei P.A., (2016) Integration of storage and renewable energy into district heating systems: A review of modelling and optimization, Solar Energy, 136, pp. 49-64.

[10] Salvestroni M., Pierucci G., Fagioli F., Pourreza A., Messeri M., Taddei F., Hosouli S., Rashidi H., De Lucia M., (2019) Design of a seasonal storage for a solar district heating in Florence, IOP Conf. Series: Materials Science and Engineering, 556, 012026.

[11] Reiter P., Poier H., Holter C. (2016) BIG Solar Graz: Solar district heating in Graz $-500,000 \mathrm{~m}^{2}$ for $20 \%$ solar fraction, Energy Procedia, 91, pp. 578584.

[12] Guadalfajara M., Miguel A. Lozano M.A., Serra L.M. (2014) Analysis of Large Thermal Energy Storage for Solar District Heating, Eurotherm Seminar \#99. Advances in Thermal Energy Storage.

[13] Trier D., Skov C.K., Sørensen S.S., Bava F., (2018) Solar district heating trends and possibilities. Characteristics of Ground-Mounted Systems for Screening of Land Use Requirements and Feasibility. Technical Report of IEA SHC Task 52, Subtask B Methodologies, Tools and Case studies for Urban Energy concepts. PlanEnergi, Copenhagen, Denmark.

[14] Tian Z., Zhang S., Deng J., Fan J., Huang J., Kong W., Perers B., Furbo S. (2019) Large-scale solar district heating plants in Danish smart thermal grid: Developments and recent trends, Energy Conversion and Management, 189, pp. 67-80 .

[15] *** Solargis, (accessed February 2020), https://globalsolaratlas.info/download/romania [16]*** Bosch Thermotechnology, https://www.bosch-thermotechnology.com [17] *** Bt provider, Tabeau Software, https://www.nrcan.gc.ca/maps-toolspublications/tools/data-analysis-softwaremodelling/retscreen/7465

[18] Sorknæs P. (2018) Simulation method for a pit seasonal thermal energy storage system with a heat pump in a district heating system, Energy, 152, pp. 533-538

[19] Mangold D., Schmidt T., Müller-Steinhagen H., (2004) Seasonal Thermal Energy Storage in Germany, Structural Engineering International, 14(3), pp. 230232, DOI: $10.2749 / 101686604777963739$

[20] Winterscheid C., Schmidt T., Gram district heating monitoring data evaluation for the years 2016-2017, Solites (Steinbeis Research Institute for Solar and Sustainable Thermal Energy Systems), 2019, Stuttgart, Germany (www.solites.de).

[21] Calin C., Rusu E., Dragomir S. (2019) Risk analysis on the heat pump system to use for building heating, in urban area, Mechanical Testing and Diagnosis, 2 (IX), pp. 5-10. 